\title{
A Remote Sensing Approach to Understanding Patterns of Secondary Succession in Tropical Forest
}

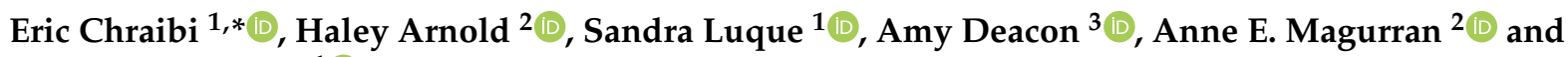 \\ Jean-Baptiste Féret ${ }^{1}$ (D) \\ 1 TETIS (Land, Environment, Remote Sensing and Spatial Information Unit) INRAE, AgroParisTech, \\ Université Montpellier, 34000 Montpellier, France; sandra.luque@inrae.fr (S.L.); \\ jean-baptiste.feret@inrae.fr (J.-B.F.) \\ 2 Centre for Biological Diversity, School of Biology, University of St. Andrews, St. Andrews KY16 9TF, UK; \\ ha33@st-andrews.ac.uk (H.A.); aem1@st-andrews.ac.uk (A.E.M.) \\ 3 Department of Life Sciences, The University of the West Indies, St. Augustine, Trinidad and Tobago; \\ Amy.Deacon@sta.uwi.edu \\ * Correspondence: eric.chraibi@inrae.fr; Tel.: +336-49-15-53-95
}

Citation: Chraibi, E.; Arnold, H.; Luque, S.; Deacon, A.; Magurran, A.E.; Féret, J.-B. A Remote Sensing Approach to Understanding Patterns of Secondary Succession in Tropical Forest. Remote Sens. 2021, 13, 2148. https://doi.org/10.3390/rs13112148

Academic Editors: Duccio Rocchini and Valerio Amici

Received: 4 May 2021

Accepted: 27 May 2021

Published: 30 May 2021

Publisher's Note: MDPI stays neutral with regard to jurisdictional claims in published maps and institutional affiliations.

Copyright: (c) 2021 by the authors. Licensee MDPI, Basel, Switzerland. This article is an open access article distributed under the terms and conditions of the Creative Commons Attribution (CC BY) license (https:// creativecommons.org/licenses/by/ $4.0 /)$.

\begin{abstract}
Monitoring biodiversity on a global scale is a major challenge for biodiversity conservation. Field assessments commonly used to assess patterns of biodiversity and habitat condition are costly, challenging, and restricted to small spatial scales. As ecosystems face increasing anthropogenic pressures, it is important that we find ways to assess patterns of biodiversity more efficiently. Remote sensing has the potential to support understanding of landscape-level ecological processes. In this study, we considered cacao agroforests at different stages of secondary succession, and primary forest in the Northern Range of Trinidad, West Indies. We assessed changes in tree biodiversity over succession using both field data, and data derived from remote sensing. We then evaluated the strengths and limitations of each method, exploring the potential for expanding field data by using remote sensing techniques to investigate landscape-level patterns of forest condition and regeneration. Remote sensing and field data provided different insights into tree species compositional changes, and patterns of alpha- and beta-diversity. The results highlight the potential of remote sensing for detecting patterns of compositional change in forests, and for expanding on field data in order to better understand landscape-level patterns of forest diversity.
\end{abstract}

Keywords: diversity indices; agroforestry; Sentinel-2; biodiversity monitoring; alpha-diversity; beta-diversity

\section{Introduction}

Biodiversity is under unprecedented threat [1-4], driven largely by habitat loss [5-7]. Rapid changes in biodiversity [8-10] put ecosystem functioning at risk and jeopardize the essential services that we rely on [11]. While the Aichi global biodiversity targets [12] succeeded in bringing global attention to concerns about biodiversity, most of the targets set for 2020 were not met, highlighting the need for better communication, an improved knowledge of operational monitoring techniques, and action for biodiversity conservation. Here we refer to biodiversity as the variety of life distributed heterogeneously across the Earth. We mainly focus on the variability of biodiversity in tropical forests [13]; with a focus on tree species richness and evenness, while considering compositional change over succession.

Although tropical forests are important biodiversity hotspots which support many endemic and threatened species [14-19], these habitats continue to experience record losses across the globe. Worldwide, the reduction in the extent of primary forest in 2019 was $2.8 \%$ higher than in previous years, the third highest loss since the turn of the century according to the latest Global Forest Watch report [20]. As the proportion of secondary and 
human-planted forest continues to grow [21-24], it is becoming increasingly important to understand the contributions these forests make to biodiversity conservation [25].

Biodiversity is commonly monitored using field-based approaches [26] which can be difficult, slow, and expensive to conduct [27]. These challenges may be especially acute in the biodiversity-rich tropical regions where sites tend to be less accessible, the terrain can be more difficult to navigate, and infrastructure is often limited. Consequently, scaling up field-based biodiversity research, which is essential for efficient monitoring and informed policymaking [28], has proven challenging [29,30]. Surveying extended regions therefore demands new strategies [31].

Remote sensing (RS) presents a solution for vegetation monitoring [32-34], as its coverage capacity can be leveraged for large-scale biodiversity analyses [35-37]. Vegetation studies based on remote sensing data have already proven effective for species identification [38-40], species diversity estimation and community mapping [41,42], and for estimating plant functional traits [43-45]. Analyzing biodiversity change over secondary forest succession using remote sensing [46,47] is a new development towards an improved monitoring of biodiversity in tropical forests. Among the many approaches used to link remote sensing data with biodiversity, the spectral variation hypothesis (SVH [48]) shows strong potential. The SVH explicitly assumes that spectral heterogeneity measured among pixels of an image is linked to landscape or species heterogeneity, depending on the spatial resolution of the image and the scale of analysis, and can therefore be linked to taxonomic and functional diversity. This assumption is justified by the contribution of functional traits and properties of the plants and canopies to the spectrum measured. The measured spectrum can therefore be understood as an integration of vegetation properties [49-51]. While it may be impossible to directly link a spectrum and a species for every scale of measurement [35], the SVH allows us to explore the variation in optical information in an effort to reveal the latent part of the signal linked with taxonomic diversity. Such methods have already been used to map taxonomic diversity based on remote sensing [51-54]. Given that different ways of utilizing this framework continue to be developed, no consensus has yet been reached on one single method [55] or application [56].

In this study, we surveyed forest sites on the island of Trinidad in the Caribbean at different stages of regeneration following cacao (Theobroma cacao) agroforest abandonment. We defined cacao agroforests as forested areas cultivated predominantly for cacao production, but which included other tree and shrub species, including shade trees. We quantified tree species alpha-diversity (species richness and evenness) and beta-diversity (change in species composition over succession) using field survey data and Sentinel-2 data, in order to compare the effectiveness of the two methods for monitoring biodiversity.

Tree species richness is expected to increase over succession as new species colonize abandoned cacao agroforests [57-60]. Trees are autogenic ecosystem engineers and alter the abiotic conditions of the landscape including soil fertility and stability, wind patterns, humidity, temperature, the ability of water to percolate into the soil, and the amount of light that filters through the forest canopy layers. The abiotic conditions within secondary forests change over time as more trees colonize the area and interact with the landscape. Species composition is expected to change over succession as abiotic conditions within the forest change, and more old-growth species (e.g., slow-growing, long-lived, animal-dispersed, and shade-tolerant species) dominate the assemblages [58]. Other studies indicate that while tree species richness can recover within the first 50 years of succession, species composition of secondary forests can take centuries to converge with that of primary forests $[57,59,60]$.

Remote sensing studies of successional tropical forests are scarce, and even fewer apply a single-date approach $[46,47]$ to such complex ecosystems. Based on the SVH, we are expecting that the variation in tree species diversity observed in the field will cause corresponding variation in spectral information, resulting in matching alpha- and beta-diversity indices values. 
We substantiated our results in the context of Trinidad's Northern Range forests in order to understand the variation in the beta-diversity estimated from RS data, and its potential to distinguish between forests at different stages of succession. We then used this information to produce a map of forest age for the region. Our objectives are twofold:

(i) to assess patterns of tree species diversity change over succession, and (ii) to compare the results generated from field and RS data. We address the strengths and limitations of using field and RS data, and identify complementarities between the two methods, in order to develop operational models of biodiversity monitoring.

\section{Materials and Methods}

\subsection{Study Area and Field Plot Network}

This study was conducted in Trinidad and Tobago, a twin-island nation in the Caribbean off the coast of Venezuela. Trinidad has a long history of cacao farming; it was the third largest cacao producer in the world in 1830, and the cacao industry dominated its economy from approximately 1866 to 1920 [61]. Though the cacao industry has declined and many old cacao estates have been abandoned, much of Trinidad's land has been transformed by cacao production and there are still many cacao farmers today (an estimated 3500 farmers in 2004 [61,62]).

Twenty-nine forest patches were surveyed on foot in the Northern Range of Trinidad (Table 1). Only 19 of these sites are used in this study because of persistent cloud cover, which precluded remote sensing analysis (Figure 1; see Section 2.3). Together, the sites represent around 100 years of secondary forest succession, including active cacao agroforests, secondary forests regenerating following cacao agroforest abandonment, and primary forest (Figure 1). We used a chronosequence approach whereby the number of years since each cacao agroforest site was abandoned is used as a proxy for successional age. This approach assumes that secondary forests are transitioning through succession at a similar rate.

Table 1. Table of sites surveyed. Grayed out sites were not used because of cloud cover.

\begin{tabular}{|c|c|c|c|c|c|}
\hline Site & Age (Years) & Altitude (m) & Site & Age (Years) & Altitude (m) \\
\hline AME & 0 & 207 & VCR & 65 & 352 \\
\hline UpLop1 & 0 & 550 & BR1 & 70 & 321 \\
\hline $\mathrm{OA}$ & 0 & 100 & UC1 & 75 & 158 \\
\hline SASC & 0 & 92 & OT1 & 80 & 185 \\
\hline ERE & 0 & 6 & MW8 & 80 & 244 \\
\hline Lop1 & 0 & 167 & LAL & 80 & 471 \\
\hline BSC & 0 & 52 & MSB & 100 & 267 \\
\hline Sim1 & 25 & 211 & LHC & 100 & 360 \\
\hline MSBT & 25 & 467 & SCA & 100 & 217 \\
\hline BST & 30 & 100 & GL & 100 & 373 \\
\hline CMA & 40 & 122 & LLP & 200 & 528 \\
\hline $\mathrm{CH}$ & 40 & 90 & LALP & 200 & 550 \\
\hline BR2 & 45 & 334 & NRGS & 200 & 297 \\
\hline OT2 & 50 & 221 & VCRP & 200 & 148 \\
\hline C1 & 50 & 149 & & & \\
\hline
\end{tabular}

The field sites were chosen based on expert opinion to account for variability in environmental variables (including matrix habitat type, altitude, land gradient, forest type, and land-use history in Supplementary Materials) and based on our ability to obtain reliable ages and land-use history information. The successional age and land-use history of each site was gathered from historical records, including those held at the National Archives of Trinidad and Tobago, and from local knowledge. Sites were all 1-5 ha, with over 50\% canopy cover and trees over $5 \mathrm{~m}$ tall. The sites were spread throughout the southern slopes of the Northern Range (Figure 1), which are dominated by seasonal evergreen forest [63]. The boundaries of each site were determined from landmarks which are commonly used as boundary markers such as the crotons Cordyline fruticosa, and from local knowledge [64]. 
All sites were over $0.8 \mathrm{~km}$ away from each other, and within $0.14 \mathrm{~km}$ of a larger tract of forest [65]. 


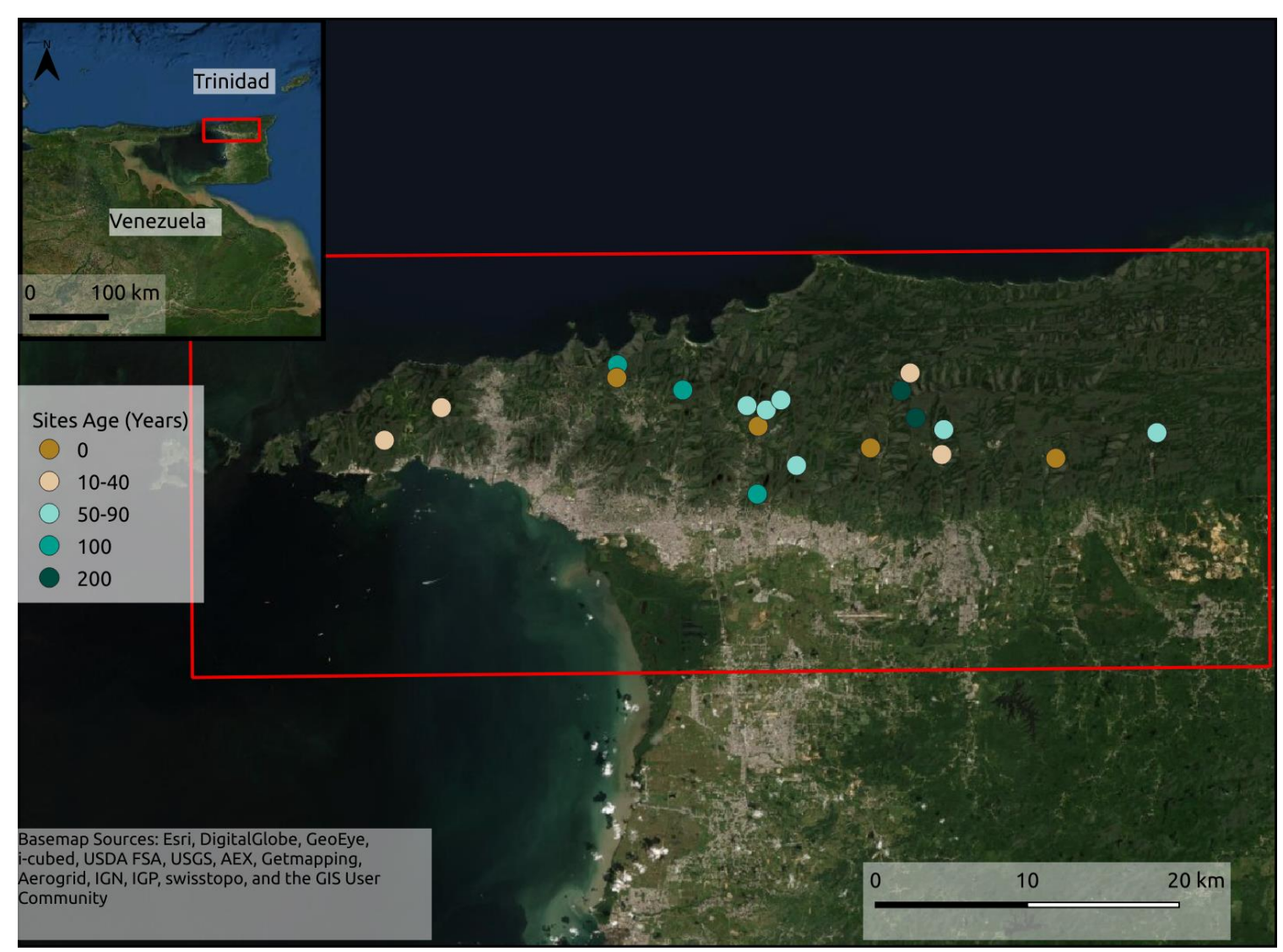

Figure 1. Site locations in the Northern Range of Trinidad ( $n=19$ total). There were four active sites ( 0 years of regeneration), four 10-40 yo, six 50-80 yo, two 100 yo secondary forests, and two primary forest sites.

Active cacao agroforestry systems were planted primarily with cacao trees, with some shade trees such as mountain immortelle (Erythrina poeppigiana) and other crop trees such as mango (Mangifera indica) and citrus (Citrus sp.). The cacao trees were pruned so that they remained short and easy to harvest, and the ground vegetation and epiphytes on the cacao trees were often removed. The secondary forests were regenerating from abandoned cacao agroforests and were in the range of c.20-100 years post-abandonment. The primary forests had no record or indication of disturbance, and had not been disturbed in local memory. Primary forest sites were given a conservative age estimate of 200 years old for the regression analyses.

\subsection{Survey Methods}

The 29 forest sites were surveyed between November 2018 and August 2019. All of the trees (woody vegetation $>3 \mathrm{~m}$ tall and $>6 \mathrm{~cm} \mathrm{DBH}$ ) within five metres of a $50 \mathrm{~m}$ transect line were identified to the species level [64]. Transects were randomly placed and oriented within each site using a random number table. If a transect line reached an impassable obstacle, the path was diverted by 90 degrees. Samples and photographs were taken of the trees, and the species were re-identified by the National Herbarium of Trinidad and Tobago where necessary. Topographical and environmental data were collected, including altitude using a GPS, land gradient using an inclinometer, and canopy cover using a densiometer.

\subsection{Satellite Imaging Surveys}

Sentinel-2 (S2) is a constellation of two satellites launched by ESA in 2015 as part of the Copernicus Earth observation program. S2 acquires multispectral images in the optical domain (visible, near infrared, and short wave infrared), and the combination of spectral bands acquired by the multispectral sensors are especially designed for sensitivity 
to biophysical parameters of vegetation [66]. S2 ensures global coverage, and the repetition time of five days between each acquisition increases the odds of observing areas that are often obscured by cloud cover such as tropical forests.

Satellite images were accessed through the Copernicus open access hub (Copernicus Open Access Hub, 2020) in Level-1C products, which correspond to Top-Of-Atmosphere reflectance images in cartographic geometry and UTM/WGS84 projection. These Level$1 \mathrm{C}$ images were atmospherically corrected and converted into Level-2A images with the Overland software developed by Airbus [67]. All the plots surveyed in the field are located on a single S2 $110 \times 110 \mathrm{~km}^{2}$ tile (T20PPS of the S2 tiling grid), allowing the use of a single image to observe all the plots at once. We used the image acquired on 13 February 2019 (wet season), which had $<50 \%$ cloud cover and covered the largest number of plots.

\subsection{Diversity Indices Computed from Ground Inventories}

\subsubsection{Alpha-Diversity}

To quantify tree species' alpha-diversity, we used the exponential form of the Shannon diversity measure, also known as Hill number of order 1 [68], hereafter named Shannon's $D$. Shannon's $D$ was quantified using the following formula [69]:

$$
\text { Shannon's } D=\exp \left(-\sum_{i=1}^{S} p_{i} \ln p_{i}\right)
$$

Here, $S$ is the total number of species in the assemblage, and $p_{i}$ is the proportion of individuals of the $i$ th species. Shannon's $D$ (equivalent to expH) incorporates information on both species richness and evenness. Shannon's $D$ reports the number of species that would be present at a site if all the species there were equally abundant. As such, it provides a readily interpretable measure of the evenness of species abundances at a site, in relation to the richness of that site. We made fair comparisons of estimates of Shannon's $D$ for the field data using extrapolated rarefaction for sample size of 100 trees, to account for differences in sampling effort between sites (iNEXT package in $r$ statistical software; $[70,71]$ ).

\subsubsection{Beta-Diversity}

We used Bray Curtis dissimilarity (BC) [72] as a measure of compositional dissimilarity between plots. $B C$ is a commonly used index that quantifies the dissimilarity in species composition between two assemblages weighted by species abundances:

$$
B C_{U V}=1-\frac{2 \sum_{i=1}^{N} \min \left(U_{i}, V_{i}\right)}{\sum_{i=1}^{N}\left(U_{i}+V_{i}\right)}
$$

where $U_{i}$ and $V_{i}$ are the abundances of the $i$ th species in the first and second assemblage, respectively, and $\min (U, V)$ is the lowest abundance of the $i$ th species (depending on whether the abundance is smaller in assemblage $U$ or $V$ ), and including only species which are present in both assemblages [72,73]. $B C$ is bound between 0 and 1 , where higher values indicate greater compositional dissimilarity and lower values indicate greater similarity between sites.

\subsubsection{Remote Sensing Analyses}

An increasing number of approaches are being proposed to monitor plant biodiversity from remotely sensed images $[36,74]$. Supervised approaches are based on the training of models with remote sensing data and field data. However, most of these methods are not easily reproducible, as their reliability depends on the quality and abundance of the training data. Aiming for a more general and reproducible approach, we opted for a method requiring minimum supervision and no ground information for calibration. We used the R package biodivMapR [75], which includes an adaptation of the method initially developed by Féret and Asner [52] for the analysis of airborne imaging spectroscopy. This method aims to extract information corresponding to the spatial heterogeneity of spectral information, and to express it as diversity indices commonly used in ecology. It is based 
on a series of image pre-processing steps, followed by clustering, aimed at assigning a "spectral species" to each pixel. This population of spectral species intends to automatically discriminate among optically distinguishable functional types, defined as 'optical types' by Ustin and Gamon [76], and can then be inventoried for a given spatial unit in order to compute various diversity indices, including Shannon's $D$ and $B C$. Finally, these diversity indices are mapped based on a fixed grid.

As the method uses spatial heterogeneity of spectral information to produce diversity indices, it is potentially sensitive to multiple factors extrinsic to vegetation properties that can impact the radiometric properties measured by a satellite. These factors include atmospheric perturbations such as cloud and haze, geometric and topographic effects leading to changes in illumination, and sensor artefacts such as Spectral Response Nonuniformity (SRNU) described in the Sentinel-2 Data Quality Report [77], among others. Therefore, proper image data pre-processing is crucial for relating spectral heterogeneity to vegetation diversity.

In our study, all available images showed significant cloud cover, which makes preprocessing and data filtering even more important. We first applied a series of radiometric filters in order to discard non-vegetated pixels (NDVI thresholding), as well as pixels suspected to be in shaded areas with an insufficient signal (NIR thresholding), or perturbed by atmospheric effects (blue thresholding). Then, we performed a Principal Component Analysis (PCA) from a correlation matrix on the remaining pixels, and selected components based on visual interpretation in order to discard components showing unwanted artefacts. Finally, we performed K-Means clustering, with 50 clusters, on the selected components.

The elementary surface units used to produce diversity maps depend on the image spatial resolution and on the ecological processes at work. Here, we produced alphaand beta-diversity maps over the S2 tile using 1ha elementary surface units. The map corresponding to alpha-diversity corresponds to the computation of Shannon's $D$ for each of these elementary surface units. The map corresponding to beta-diversity corresponds to the computation of $B C$ for a random selection of elementary surface units over the tile, followed by a Principal Coordinate Analysis (PCoA) [78] applied to the $B C$ matrix in order to transpose the dissimilarity space into a 3-dimensional space. The generalization of the PCoA to all elementary surface units was then obtained by applying a nearest-neighbour procedure, enabling visualization (see Féret and Boissieu [75] for additional details). These diversity indices can also be computed from the pre-defined field plot network in order to use the exact spatial extent of the sites, and to enable proper comparison between ground observations and remotely sensed information for validation, as illustrated in the next section.

\subsection{Comparison between Ground Observations and Remotely Sensed Information}

\subsubsection{Spatial Sampling of Satellite Images}

The computation of spectral diversity using the original field plots may result in difficulties when comparing diversity among plots due to heterogeneity in size and shape. Moreover, diversity indices derived from S2 data require a minimum number of pixels in order to compute reliable estimates of the diversity and spectral dissimilarity between forest plots. In order to overcome these difficulties, we applied a procedure designed to harmonize size and shape among plots.

First, we identified the pole of inaccessibility for each field plot, corresponding to the point maximizing the distance from all borders (Figure 2). The average distance between the pole of inaccessibility and the closest plot boundary was $47 \mathrm{~m}$. Then we defined a buffer around each pole of inaccessibility, leading to circular plots of a $60 \mathrm{~m}$ radius, corresponding to 1.13 ha and 113 pixels in the raster data. This buffer size offered the best trade-off between the number of pixels and the spatial match with original plot boundaries. This procedure ensured consistency in the spatial units used, which is especially important when using indices that are sensitive to sample size such as Shannon's $D$. 


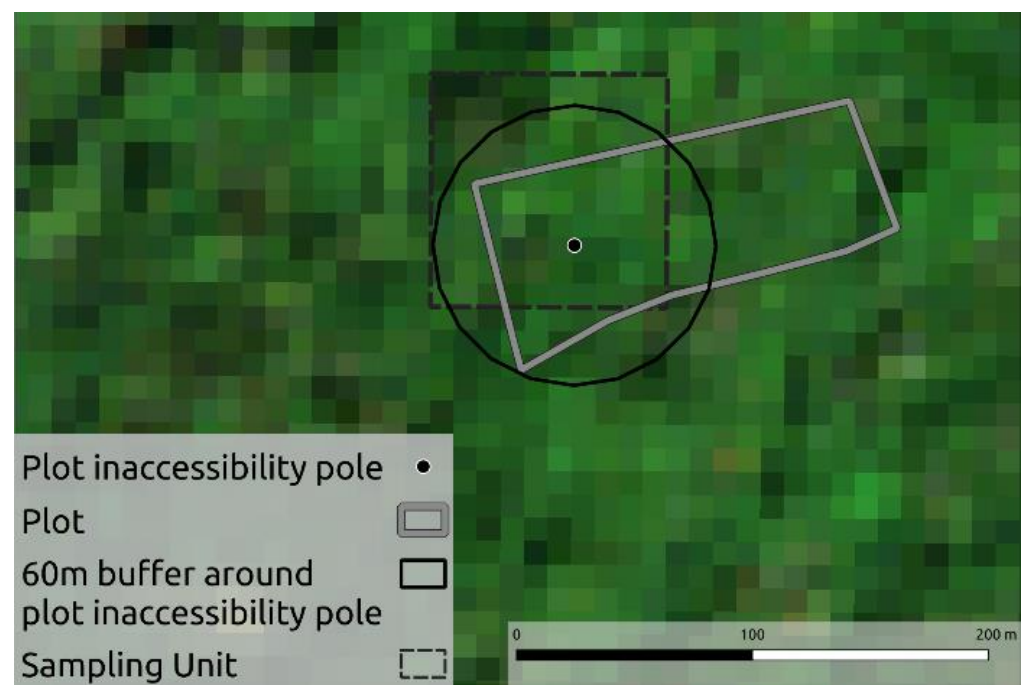

Figure 2. Illustration of the field plot LHC defined by its original contour (gray boundaries), the corresponding inaccessibility pole and $60 \mathrm{~m}$ radius circular buffer, and the 1 ha sampling unit defined in biodivMapR when mapping diversity indices over the whole image. The background corresponds to the RGB color composite of the original S2 image with $10 \mathrm{~m}$ spatial resolution.

\subsubsection{Alpha and Beta-Diversity Analyses}

The field and RS Shannon's $D$ results were compared using a Spearman correlation coefficient, which computes the correlation of two variables based on their rank [79].

A 0.5 quantile regression [80] was used to further test whether $B C$ changes with increasing age difference between sites. Quantile regressions were used because they are more robust to unequal variance and outliers than standard linear regressions [81,82]. We used a tanglegram dendextend package [83] to compare the extent of concordance between the field and RS-derived $B C$ results. To do this, we created a dendrogram for the field $B C$ results and for the RS-derived $B C$ results using agglomerative nesting, hierarchical clustering, agnes function in cluster package R, [84] and the Ward method. Different methods within the untangle function in dendextend were used to optimise the alignment between the two dendrograms. The degree of agreement between the two dendrograms was expressed as the entanglement metric, where zero indicates no entanglement and one is full entanglement. A cophenetic correlation coefficient was also used to assess the alignment between the two dendrograms (cor_cophenetic function R; Spearman). Cophenetic correlation coefficient is the correlation between the cophenetic distance matrices of the two trees. Cophenetic correlation is bound between -1 and 1 , where values closer to 0 indicate that there is no significant correlation between the two dendrograms.

\subsubsection{Mapping Forest Age}

While land cover maps that include different forest types have already been produced for this region [85], in this particular study we also explored the possibility of using field data in conjunction with satellite data to produce a map of forest successional age. We hypothesized that part of the variation in the spectral species produced from S2 data is linked to the successional age of each forest site. Therefore, we evaluated the relationship between PCoAs from the S2-based $B C$ and forest age in the 19 surveyed forest sites, and used the most relevant axis to generate a map of forest ages in the region of interest.

\section{Results}

\subsection{Alpha Diversity}

There was a significant correlation between Shannon's $D$ and forest age using the field data $\left(r_{s}=0.50, p=0.03\right.$; Spearman; Figure $\left.3 \mathrm{~A}\right)$, but no correlation between remotely sensed Shannon's $D$ and forest age $\left(r_{s}=0.05, p=0.85\right.$; Spearman; Figure $\left.3 B\right)$. There was 
also no correlation between remotely sensed and field-derived Shannon's $D\left(\mathrm{r}_{\mathrm{s}}=-0.37\right.$, $p=0.21$; Spearman).

(A)

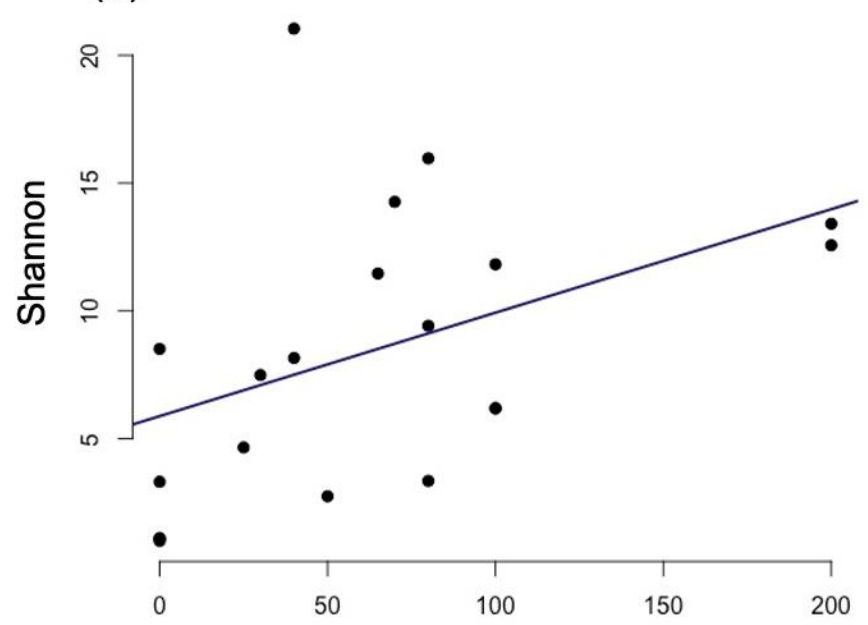

(B)

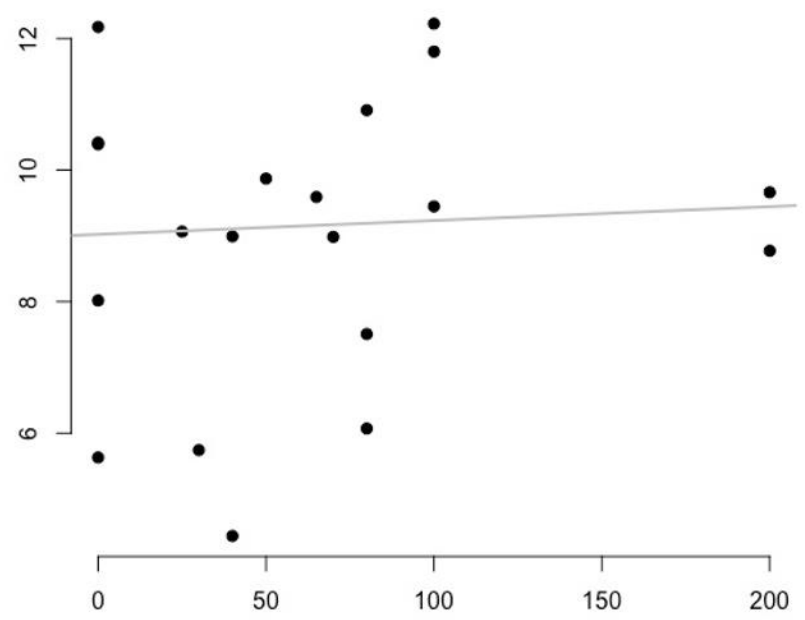

Age since abandonment (years)

Figure 3. Comparison between plot age and Shannon's $D$ computed from field data (A) and S2 images (B). Primary forest sites are given a conservative age estimate of 200 years old for these analyses.

\subsection{Beta Diversity}

\subsubsection{Bray-Curtis Dissimilarity}

The $B C$ values quantified from field data and from the $\mathrm{S} 2$ image are presented as pairwise dissimilarity matrices (Figure 4). In the field-based data (Figure 4A), each primary site was compositionally unique $(B C>0.98$ between primary sites and all other sites; $B C=0.84$ between primary sites). The actively managed sites were all more compositionally similar to each other than to the secondary and primary forest sites $(\overline{B C}=0.58$ between all active plots, $\overline{B C}=0.76$ across all sites).

The pairwise $B C$ derived from the $\mathrm{S} 2$ analysis (Figure $4 \mathrm{~B}$ ) showed different patterns from those derived from field data. Active sites were strongly dissimilar to all other age categories, particularly with $>80$ yo sites $(\overline{B C}>0.95)$. Dissimilarity between active sites and other sites tended to increase with increasing age difference. Secondary forest sites exhibited lower dissimilarities ( $\overline{B C}=0.48$ for all plots over $80 \mathrm{yo}$ ), with the lowest values found between plots of 100 yo and older $(\overline{B C}=0.41)$.

A 0.5 quantile regression showed there was a significant increase in compositional change $(B C)$ (Figure 5) with increasing age difference between sites for both the remote sensing data $\left(\mathrm{t}_{(169,171)}=5.18, p<0.001\right)$ and the field data $\left(\mathrm{t}_{(169,171)}=6.70, p<0.001\right)$. 

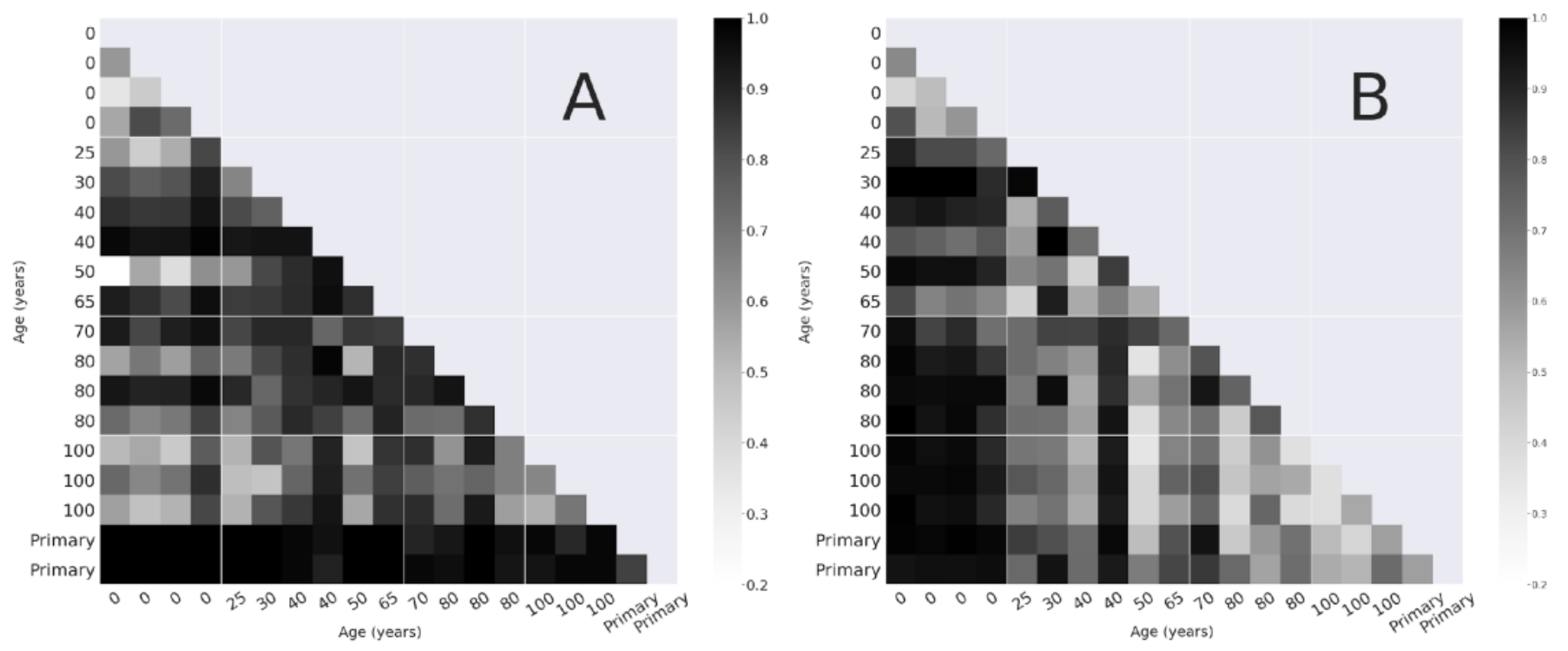

Figure 4. Pairwise Bray Curtis dissimilarity between sites based on the field surveys (A), and remote sensing (B) sorted by regeneration time.

\section{(A)}

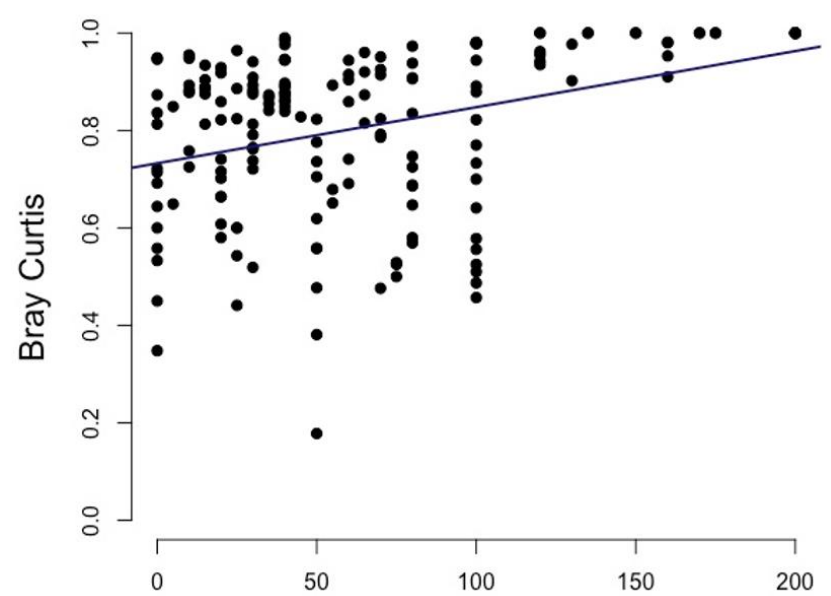

(B)

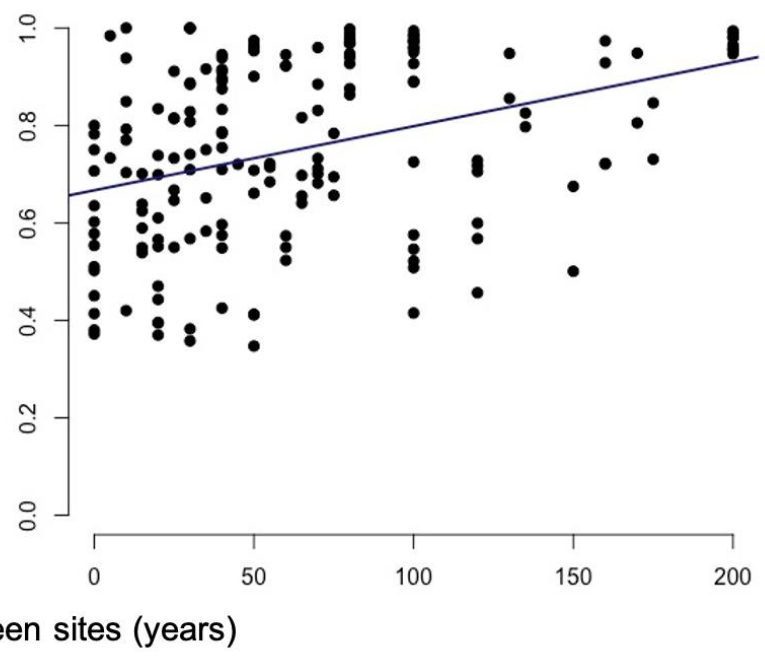

Figure 5. Results from a 0.5 quantile regression of Bray-Curtis and age difference between site pairs for field data (A) and for remote sensing data (B).

A tanglegram was used to further explore the concordance in patterns of $B C$ between the field and RS data. The tanglegram (Figure 6) shows the dendrograms for the field data (left) and RS data (right). Corresponding sites are connected by gray lines, and sites are labeled according to their age category: (A) active cacao agroforests, (B) 25-50 yo, (C) 60-80 yo, (D) > 100 yo, and (E) primary forest. Although the two dendrograms align well (entanglement $=0.15$ using the step2side method), there is no significant correlation between the topologies of the field and RS dendrograms (cophenetic correlation $=0.08$ ).

\subsubsection{Ordination of Bray Curtis Dissimilarity Computed from Sentinel-2}

We used PCoA ordination to compute the position of each site in three-dimensional space for the RS data. In this representation, the distance between two sites is based on $B C$. Figure 7 shows the values for the first two dimensions of the PCoA when the $B C$ dissimilarity matrix was computed using only the pixels inside the original plot boundaries 
(Figure 7A). The first component of the PCoA consistently appeared as a relevant indicator of age category among plots, which is consistent with the age gradient observed on the dissimilarity matrix (Figure 4B). The combination of the first two PCoA dimensions revealed three main groups of points: (1) active with low values of pco1, (2) secondary forest plots with age values ranging from 25 to 80 yo, (3) a mix of some recovering plots and all older plots with high values of pco1. As the PCoA is a data-driven process, a second analysis was performed following a scenario designed to test the consistency of our results when using dissimilarity maps produced with biodivMapR over the full image; we selected the 1 ha elementary surface units, including the inaccessibility pole corresponding to each field plot, in order to observe their distribution along the two first components of the PCoA (Figures 2 and 7B). The distribution of the field plots along these two components was complemented with 300 random 1 ha elementary surface units. This distribution showed the same trend with an age gradient following pco1, confirming that the observations obtained from the analysis of field plots with only maximum consistency in spatial footprint are still valid when analyzing a full S2 tile.

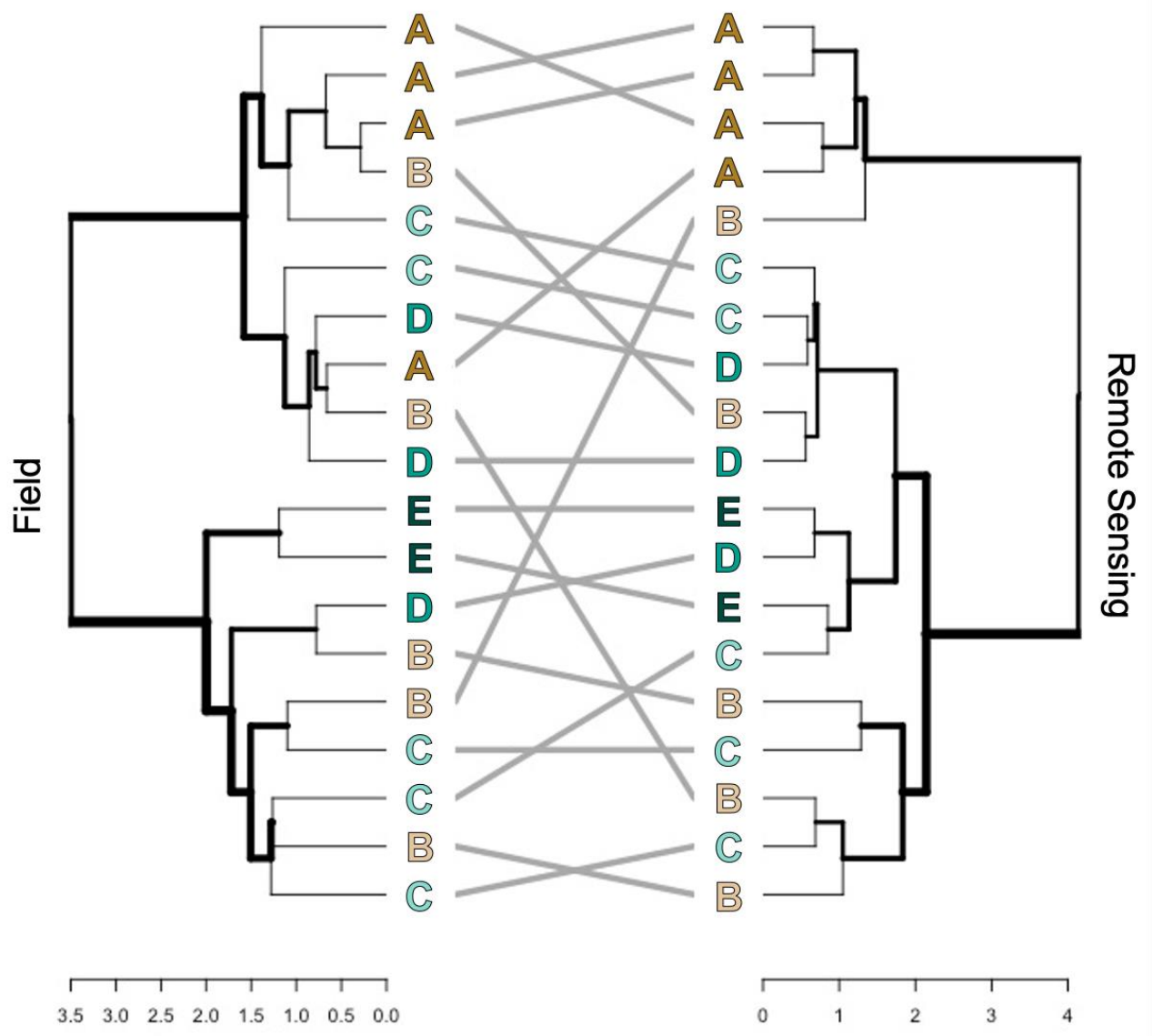

Figure 6. Tanglegram comparing dendrograms of $B C$ between the field data (left) and RS data (right) based on hierarchical clustering. Gray lines connect corresponding sites between the two dendrograms, and sites are labeled according to their age grouping: (A) active sites, (B) 25-50 yo, (C) 60-80 yo, (D) >100 yo, (E) primary forest sites.

\subsection{Mapping Forest Age}

The first component of the PCoA, applied to the $B C$ indices computed from the satellite image, showed a strong correlation with forest age $\left(R^{2}=0.89\right.$, Figure $\left.7 B\right)$. In order to take advantage of this relationship, we used a simple linear model to estimate forest age over the whole image (Figure 8). However, because the high values of the first component (pco1) for 100-year-old secondary forests and 200-year-old primary forests overlap at approximately 0.4 (the highest values found over the image) the maximum forest age estimated was 
120 years old. More than $20 \%$ of the region was estimated to consist of forests in early successional stages (less than 10 years old). The young secondary forests were generally estimated to be located on the south and west of the Northern Range, whereas most of the northern region of the island was classified as older forest (Figure 9).
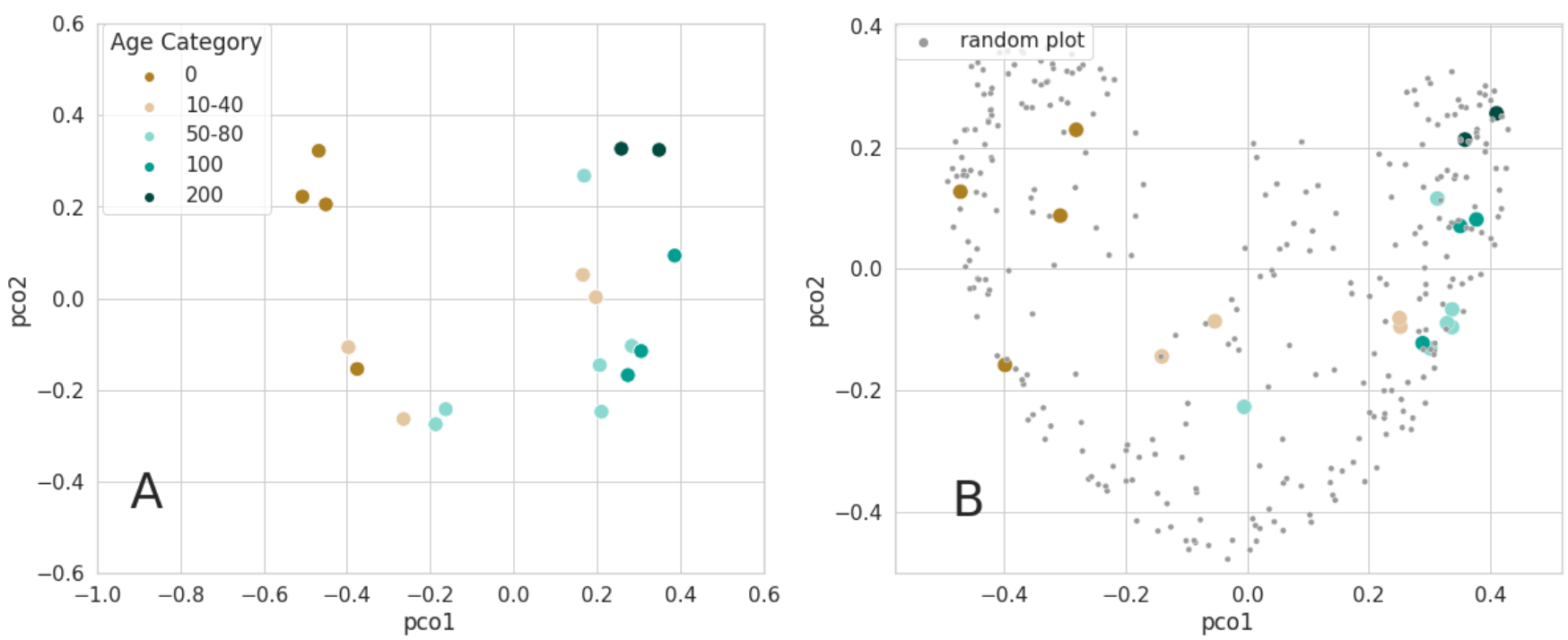

Figure 7. Projection of the plots using the PCoA components as ordination technique for $B C$ : (A) the dissimilarity matrix derived from a plot network only, using the original plot boundaries; (B) biodivMapR elementary surface units overlapping the plots' inaccessibility poles were used. All the elementary units from the northern range of Trinidad were used as an input to the PCoA (shown in gray).

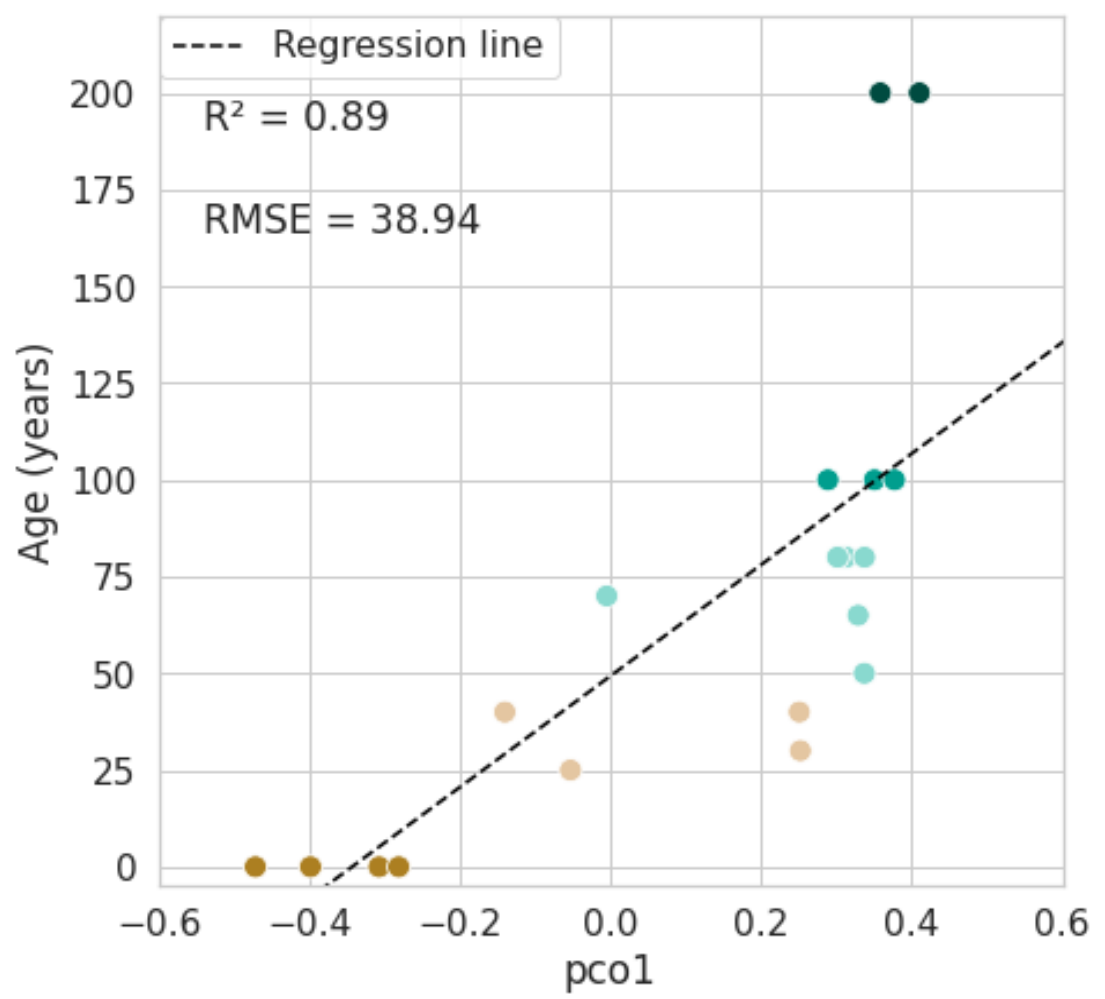

Figure 8. Relationship between plot age in years and the values of the first component of the PCoA. 


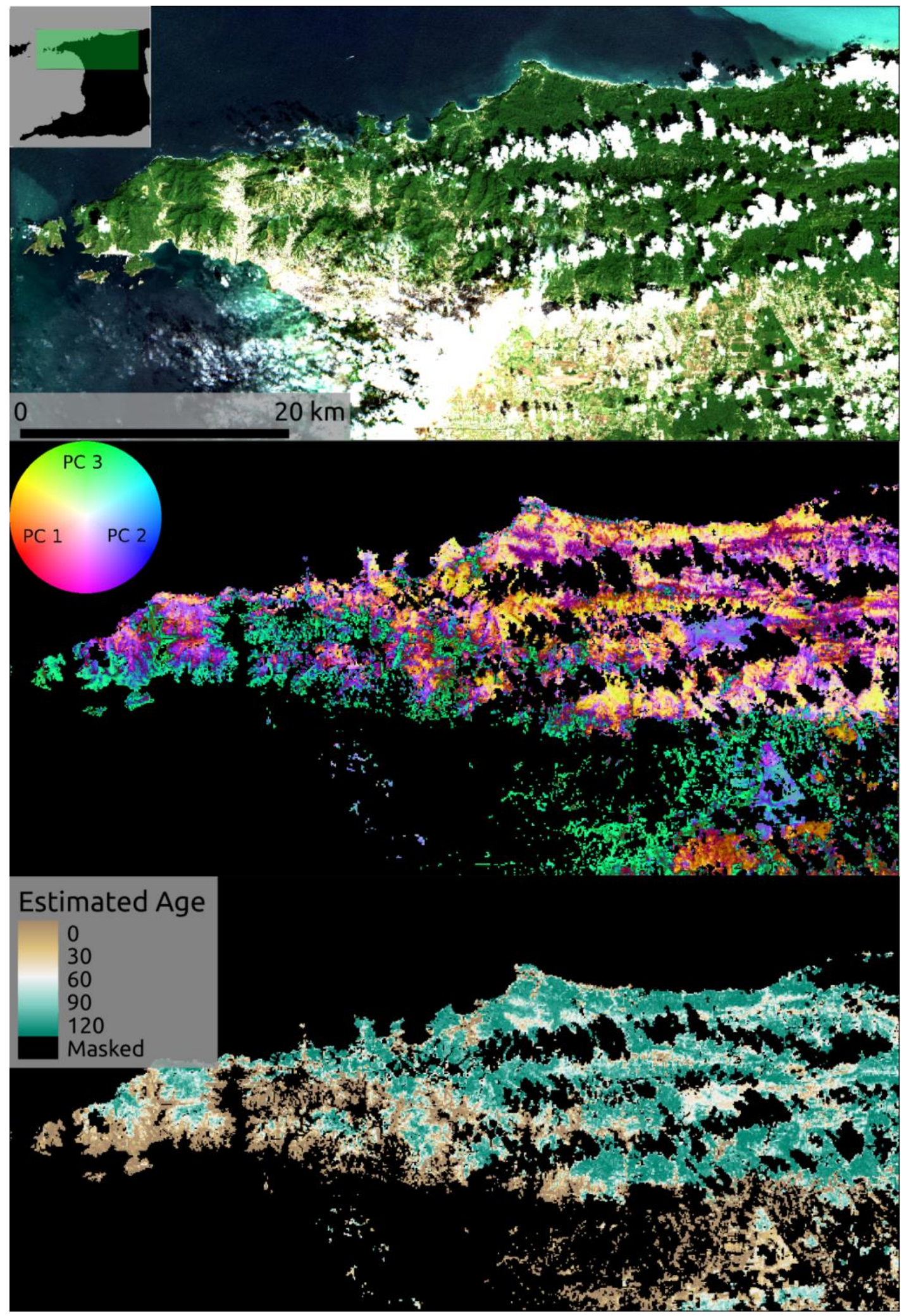

Figure 9. RGB composite from S2 image acquired in 13 February 2019 and used to compute diversity metrics (top), dissimilarity map based on the RGB representation of the three components of the PCoA derived from dissimilarity analysis (middle), and age estimates based on the first Principal Coordinate (bottom). 


\section{Discussion}

There was a significant increase in the field-based Shannon's D with forest age [64], but no evidence of a significant relationship between RS-based Shannon's $D$ and forest age. Overall, the field and RS data showed similar patterns of beta-diversity, with significantly greater turnover in species composition as the age difference between sites increased. Finer-scale patterns of beta-diversity differed between the field and RS results though, and pairwise comparisons between sites yielded different degrees of compositional dissimilarity. While the field results showed primary forests to be compositionally unique and active sites as being compositionally similar to other active sites, the RS results better captured the turnover in composition with age difference between sites. The RS did not distinguish primary sites from 100 yo sites, while the field results did. There was no overall correlation between the alpha- or beta-diversity results of the two datasets. However, the field plots' historical records made it possible to interpret RS-derived $B C$ to produce a forest age estimate over the whole region.

\subsection{Alpha and Beta-Diversity Comparison}

In agreement with the field results, other studies indicate that tree diversity tends to increase with forest age as species naturally colonize abandoned areas [24,86-88]. The RS data may not be able to capture these changes in alpha-diversity because of local spectral diversity being more strongly driven by the structure and density of vegetation than by the diversity of tree species. While other studies have had success applying hyperspectral, high-resolution data to alpha-diversity estimates through remote sensing [54], here the spatial and spectral resolution may be too coarse to capture the fine variation of spectral signatures of the species variability at a local scale (Figure 3) [89]. RS analyses at this scale may be more closely related to functional diversity of photosynthetic traits at the community scale, $[43,90,91]$ or to forest structure, $[57,92]$ rather than to tree species diversity. Furthermore, in this case, it may also be possible that the species present are not spectrally different enough to be accurately detected by Sentinel-2 [93]. The RS results may also be improved by an increased number of sites.

Both the field and RS results showed considerable turnover in species composition with forest age (Figure 4). This aligns with other studies which have found that species composition changes over succession, and that it can take centuries for tree species composition in secondary forests to converge with that of primary forests $[22,59,94,95]$. Primary sites are identified as particularly compositionally unique in the field data, indicating that species composition in secondary forests has not recovered old-growth characteristics even after c. 100 years of succession [64].

The disparity in the patterns of compositional change over time detected by the field and RS data implies that these methods prioritise different aspects of the vegetation assemblages (Figure 6). The field data may fail to distinguish some patterns of species turnover over succession due to younger saplings being recorded alongside mature trees, remnant cacao and agricultural trees persisting in the lower canopy layers of older forests, stochasticity in successional trajectories, and canopy gap dynamics in older forests $[57,96,97]$. The height and DBH thresholds for the field study were $3 \mathrm{~m}$ and $6 \mathrm{~cm}$, respectively, in order to account for all the cacao trees, which often have many thin stems and are pruned to be short for easy cultivation. These thresholds are small compared to most tree studies [54,98] and many saplings were recorded in the field. As a result, data in the field presented differences when compared to RS data, which mostly detected the canopy trees. Differences in the canopy tree composition and the sapling composition could be diminishing the distinction between younger and older secondary forest sites for the field data, driving the differences in the field and RS results.

Overall, successional processes, including changes in species composition, are highly variable and can be affected by many different factors, including: the composition of nearby forests, the condition of the soil seed bank, the amount and type of seed rain, local environmental conditions, and other abiotic factors [22,57,60,99-104]. Cacao farming 
itself can alter successional processes. Abandoned cacao agroforests already have canopy cover from the remnant cacao and shade trees which can affect local abiotic conditions, the behavior of animal seed dispersers, and the tree species that are able to colonize [22,92,105]. Cacao trees can live for over 100 years, and still occur in the understory of the oldest secondary forests in this study.

Another subject for consideration is that these analyses were based on relatively few sites. The number of field sites was restricted to those which we had permission to access, were able to access without natural barriers or impassable terrain, and where land-use history information could be obtained. The number of sites was further limited by cloud cover, which obscured some of the field sites in the RS image. It could be that comparing more sites would reveal a stronger trend in biodiversity change over secondary succession, and stronger correlations between the field and RS results.

\subsection{Mapping Forest Age}

The forest age map generated from the remote sensing $B C$ (Figure 9) shows that old-growth forest is primarily found in the north-east of the Northern Range mountains, while the southern slopes have a higher proportion of agroforest and young secondary forest. Even though the data used to inform this map were limited, and we did not have additional data with which to validate our map, these results are consistent with local knowledge. The south-eastern stretches of the Northern Range are more easily accessible and densely populated, [85] and it is likely that these areas have experienced greater human modification and disturbance.

Land cover maps produced using remote sensing and field data can deepen our understanding of both local and landscape-level ecological processes and patterns of biodiversity. For example, the matrix surrounding an agroforest can mediate its value as habitat, and the surrounding landscape can influence the speed and trajectory of secondary forest succession [100]. The ability to produce maps such as the one presented here demonstrates the potential of using remote sensing in conjunction with field data for ecological and conservation purposes, in order to assess the biological significance of certain locations and predict how ecosystems may change over time.

\section{Conclusions}

This study highlights the potential benefits of using RS to measure tropical forest biodiversity, as well as its limitations. We did not find direct correlations between diversity indices based on field and RS data. However, RS-derived $B C$ shows potential for the identification of a gradient of regeneration in abandoned cacao agroforests, as there is clear compositional dissimilarity between active cacao agroforests and secondary forests at different stages of succession. Combining accurate but laborious field data with remote sensing methods allows us to scale up our results. With RS we can extrapolate field data to assess landscape-level patterns of biodiversity and forest regeneration. RS-based indices may allow us to explore aspects of biodiversity and forest cover change that are complementary to field studies in areas that would be otherwise inaccessible. Finally, spectral diversity indicators derived from Sentinel-2 multispectral images show strong potential for monitoring biodiversity while assessing landscape level patterns. RS provides an important complementarity for improving biodiversity monitoring at the landscape level. This approach represents an opportunity to build upon these operational methods, supporting forest management practices and environmental conservation policies.

Supplementary Materials: The following are available online at https:/ / www.mdpi.com/article/10 $.3390 / \mathrm{rs} 13112148 / \mathrm{s} 1$, Table S1: Table of sites surveyed. 
Author Contributions: E.C. and H.A. both contributed equally to the manuscript, Conceptualization: E.C., H.A., J.-B.F. and S.L.; methodology, E.C., H.A. and J.-B.F.; software, E.C. and J.-B.F.; validation, E.C. and H.A.; formal analysis, E.C. and H.A.; investigation, E.C. and H.A.; resources, S.L., A.D., A.E.M. and J.-B.F.; data curation, E.C. and H.A.; writing-original draft preparation, E.C. and H.A.; writing-review and editing, E.C., H.A., S.L., A.D., A.E.M. and J.-B.F.; visualization, E.C. and H.A.; supervision, S.L., A.D., A.E.M. and J.-B.F. project administration, S.L., A.D., A.E.M. and J.-B.F. funding acquisition, J.-B.F. All authors have read and agreed to the published version of the manuscript.

Funding: E. Chraibi and J.-B. Féret acknowledge financial support from Agence Nationale de la Recherche (BioCop pro-ject-ANR-17-CE32-0001-01) A.E. Magurran acknowledges support from the Leverhulme Trust (RPG-2019-402).

Institutional Review Board Statement: Not applicable.

Informed Consent Statement: Not applicable.

Acknowledgments: The authors thank Nicholas Manchouck, James Josaphat, Keshan Mahabir, Aidan Farrell, Ada Fontrodona Eslava, Linton Arneaud, Vicki Balfour, and Shane Ballah for their fieldwork assistance. We further thank Shane Ballah, Mike Oatham, Linton Arneaud, Yasmin BakshComeau, and the technicians at The National Herbarium of Trinidad and Tobago for confirming plant identifications. Lastly, we thank all the landowners and local residents who provided historical information and allowed us to conduct surveys on their property. H. Arnold acknowledges support from the University of St Andrews through the Harold Mitchell bequest. J.-B. Féret and E. Chraibi acknowledge financial support from Agence Nationale de la Recherche (France) (BioCop project-ANR-17-CE32-0001) and TOSCA program grant of the French Space Agency (CNES) (HyperTropik/HyperBIO project). A.E. Magurran acknowledges support from the Leverhulme Trust (RPG-2019-402).

Conflicts of Interest: The authors declare no conflict of interest.

\section{References}

1. Blowes, S.A.; Supp, S.R.; Antão, L.H.; Bates, A.; Bruelheide, H.; Chase, J.M.; Moyes, F.; Magurran, A.; McGill, B.; Myers-Smith, I.H.; et al. The Geography of Biodiversity Change in Marine and Terrestrial Assemblages. Science 2019, 366, 339-345. [CrossRef]

2. Isbell, F.; Gonzalez, A.; Loreau, M.; Cowles, J.; Díaz, S.; Hector, A.; Mace, G.M.; Wardle, D.A.; O'Connor, M.I.; Duffy, J.E.; et al. Linking the Influence and Dependence of People on Biodiversity across Scales. Nature 2017, 546, 65-72. [CrossRef]

3. Magurran, A.E.; Dornelas, M. Biological Diversity in a Changing World. Philos. Trans. R. Soc. B Biol. Sci. 2010, $365,3593-3597$. [CrossRef]

4. Pereira, H.M.; Rosa, I.M.D.; Martins, I.S.; Kim, H.; Leadley, P.; Popp, A.; van Vuuren, D.P.; Hurtt, G.; Anthoni, P.; Arneth, A.; et al. Global Trends in Biodiversity and Ecosystem Services from 1900 to 2050. Biorvix 2020. [CrossRef]

5. Diamond, J.M. "Normal” extinctions of isolated populations. In Extinctions; University of Chicago Press: Chicago, IL, USA, 1984; pp. 191-246.

6. Ehrlich, P.R.; Pringle, R.M. Where Does Biodiversity Go from Here? A Grim Business-as-Usual Forecast and a Hopeful Portfolio of Partial Solutions. Proc. Natl. Acad. Sci. USA 2008, 105, 11579-11586. [CrossRef] [PubMed]

7. Semper-Pascual, A.; Decarre, J.; Baumann, M.; Busso, J.M.; Camino, M.; Gómez-Valencia, B.; Kuemmerle, T. Biodiversity Loss in Deforestation Frontiers: Linking Occupancy Modelling and Physiological Stress Indicators to Understand Local Extinctions. Biol. Conserv. 2019, 236, 281-288. [CrossRef]

8. Dornelas, M.; Gotelli, N.J.; McGill, B.; Shimadzu, H.; Moyes, F.; Sievers, C.; Magurran, A.E. Assemblage Time Series Reveal Biodiversity Change but Not Systematic Loss. Science 2014, 344, 296-299. [CrossRef]

9. McGill, B.J.; Dornelas, M.; Gotelli, N.J.; Magurran, A.E. Fifteen Forms of Biodiversity Trend in the Anthropocene. Trends Ecol. Evol. 2015, 30, 104-113. [CrossRef]

10. Newbold, T.; Hudson, L.N.; Hill, S.L.L.; Contu, S.; Lysenko, I.; Senior, R.A.; Börger, L.; Bennett, D.J.; Choimes, A.; Collen, B.; et al. Global Effects of Land Use on Local Terrestrial Biodiversity. Nature 2015, 520, 45-50. [CrossRef]

11. Cardinale, B.J.; Duffy, J.E.; Gonzalez, A.; Hooper, D.U.; Perrings, C.; Venail, P.; Narwani, A.; Mace, G.M.; Tilman, D.; Wardle, D.A.; et al. Biodiversity Loss and Its Impact on Humanity. Nature 2012, 486, 59-67. [CrossRef]

12. The Strategic Plan for Biodiversity 2011-2020 and the Aichi Biodiversity Targets. Available online: https://www.cbd.int/sp/ (accessed on 1 March 2021).

13. Gaston, K.J. Global Patterns in Biodiversity. Nature 2000, 405, 220-227. [CrossRef] [PubMed]

14. Aerts, R.; Honnay, O. Forest Restoration, Biodiversity and Ecosystem Functioning. BMC Ecol. 2011, 11, 29. [CrossRef]

15. Betts, M.G.; Wolf, C.; Ripple, W.J.; Phalan, B.; Millers, K.A.; Duarte, A.; Butchart, S.H.M.; Levi, T. Global Forest Loss Disproportionately Erodes Biodiversity in Intact Landscapes. Nature 2017, 547, 441-444. [CrossRef] 
16. Morales-Hidalgo, D.; Oswalt, S.N.; Somanathan, E. Status and Trends in Global Primary Forest, Protected Areas, and Areas Designated for Conservation of Biodiversity from the Global Forest Resources Assessment 2015. For. Ecol. Manag. 2015, 352, 68-77. [CrossRef]

17. Myers, N. The Conversion of Tropical Forests. Environ. Sci. Policy Sustain. Dev. 1980, 22, 6-13. [CrossRef]

18. Myers, N.; Mittermeier, R.A.; Mittermeier, C.G.; da Fonseca, G.A.B.; Kent, J. Biodiversity Hotspots for Conservation Priorities. Nature 2000, 403, 853-858. [CrossRef]

19. Shvidenko, A.; McCallum, I.; Nilsson, S. Forest and woodlands systems. In Ecosystems and Human Well-Being: Current State and Trends; Hassan, R., Scholes, R., Ash, N., Eds.; Island Press: Washington, DC, USA, 2005.

20. Global Forest Watch Tree Cover Loss and Gain (Global). Available online: www.globalforestwatch.org (accessed on 20 March 2021).

21. Arroyo-Rodríguez, V.; Melo, F.P.L.; Martínez-Ramos, M.; Bongers, F.; Chazdon, R.L.; Meave, J.A.; Norden, N.; Santos, B.A.; Leal, I.R.; Tabarelli, M. Multiple Successional Pathways in Human-Modified Tropical Landscapes: New Insights from Forest Succession, Forest Fragmentation and Landscape Ecology Research. Biol. Rev. 2017, 92, 326-340. [CrossRef]

22. Derroire, G.; Balvanera, P.; Castellanos-Castro, C.; Decocq, G.; Kennard, D.K.; Lebrija-Trejos, E.; Leiva, J.A.; Odén, P.-C.; Powers, J.S.; Rico-Gray, V.; et al. Resilience of Tropical Dry Forests-A Meta-Analysis of Changes in Species Diversity and Composition during Secondary Succession. Oikos 2016, 125, 1386-1397. [CrossRef]

23. Lebrija-Trejos, E.; Bongers, F.; Pérez-García, E.A.; Meave, J.A. Successional Change and Resilience of a Very Dry Tropical Deciduous Forest Following Shifting Agriculture. Biotropica 2008, 40, 422-431. [CrossRef]

24. Martin, P.A.; Newton, A.C.; Bullock, J.M. Carbon Pools Recover More Quickly than Plant Biodiversity in Tropical Secondary Forests. Proc. R. Soc. B Biol. Sci. 2013, 280, 20132236. [CrossRef] [PubMed]

25. Bernier, P.Y.; Paré, D.; Stinson, G.; Bridge, S.R.J.; Kishchuk, B.E.; Lemprière, T.C.; Thiffault, E.; Titus, B.D.; Vasbinder, W. Moving beyond the Concept of "Primary Forest" as a Metric of Forest Environment Quality. Ecol. Appl. 2017, 27, 349-354. [CrossRef]

26. Rozendaal, D.M.A.; Bongers, F.; Aide, T.M.; Alvarez-Dávila, E.; Ascarrunz, N.; Balvanera, P.; Becknell, J.M.; Bentos, T.V.; Brancalion, P.H.S.; Cabral, G.A.L.; et al. Biodiversity Recovery of Neotropical Secondary Forests. Sci. Adv. 2019,5 , eaau3114. [CrossRef] [PubMed]

27. Levrel, H.; Fontaine, B.; Henry, P.-Y.; Jiguet, F.; Julliard, R.; Kerbiriou, C.; Couvet, D. Balancing State and Volunteer Investment in Biodiversity Monitoring for the Implementation of CBD Indicators: A French Example. Ecol. Econ. 2010, 69, 1580-1586. [CrossRef]

28. Schiller, A.; Hunsaker, C.T.; Kane, M.A.; Wolfe, A.K.; Dale, V.H.; Suter, G.W.; Russell, C.S.; Pion, G.; Jensen, M.H.; Konar, V.C. Communicating Ecological Indicators to Decision Makers and the Public. Conserv. Ecol. 2001, 5, art19. [CrossRef]

29. Barton, P.S.; Cunningham, S.A.; Manning, A.D.; Gibb, H.; Lindenmayer, D.B.; Didham, R.K. The Spatial Scaling of Beta Diversity: Spatial Scaling of Beta Diversity. Glob. Ecol. Biogeogr. 2013, 22, 639-647. [CrossRef]

30. Cardinale, B.J.; Gonzalez, A.; Allington, G.R.H.; Loreau, M. Is Local Biodiversity Declining or Not? A Summary of the Debate over Analysis of Species Richness Time Trends. Biol. Conserv. 2018, 219, 175-183. [CrossRef]

31. Proença, V.; Martin, L.J.; Pereira, H.M.; Fernandez, M.; McRae, L.; Belnap, J.; Böhm, M.; Brummitt, N.; García-Moreno, J.; Gregory, R.D.; et al. Global Biodiversity Monitoring: From Data Sources to Essential Biodiversity Variables. Biol. Conserv. 2017, 213, 256-263. [CrossRef]

32. Anderson, C.B. Biodiversity Monitoring, Earth Observations and the Ecology of Scale. Ecol. Lett. 2018, 21, 1572-1585. [CrossRef]

33. Luque, S.; Pettorelli, N.; Vihervaara, P.; Wegmann, M. Improving Biodiversity Monitoring Using Satellite Remote Sensing to Provide Solutions towards the 2020 Conservation Targets. Methods Ecol. Evol. 2018, 9, 1784-1786. [CrossRef]

34. Mulatu, K.; Mora, B.; Kooistra, L.; Herold, M. Biodiversity Monitoring in Changing Tropical Forests: A Review of Approaches and New Opportunities. Remote Sens. 2017, 9, 1059. [CrossRef]

35. Rocchini, D.; Salvatori, N.; Beierkuhnlein, C.; Chiarucci, A.; de Boissieu, F.; Förster, M.; Garzon-Lopez, C.X.; Gillespie, T.W.; Hauffe, H.C.; He, K.S.; et al. From Local Spectral Species to Global Spectral Communities: A Benchmark for Ecosystem Diversity Estimate by Remote Sensing. Ecol. Inform. 2021, 61, 101195. [CrossRef]

36. Wang, R.; Gamon, J.A. Remote Sensing of Terrestrial Plant Biodiversity. Remote Sens. Environ. 2019, 231, 111218. [CrossRef]

37. Rocchini, D.; Boyd, D.S.; Féret, J.-B.; Foody, G.M.; He, K.S.; Lausch, A.; Nagendra, H.; Wegmann, M.; Pettorelli, N. Satellite Remote Sensing to Monitor Species Diversity: Potential and Pitfalls. Remote Sens. Ecol. Conserv. 2016, 2, 25-36. [CrossRef]

38. Baldeck, C.A.; Asner, G.P.; Martin, R.E.; Anderson, C.B.; Knapp, D.E.; Kellner, J.R.; Wright, S.J. Operational Tree Species Mapping in a Diverse Tropical Forest with Airborne Imaging Spectroscopy. PLoS ONE 2015, 10, e0118403. [CrossRef]

39. Clark, M.; Roberts, D.; Clark, D. Hyperspectral Discrimination of Tropical Rain Forest Tree Species at Leaf to Crown Scales. Remote Sens. Environ. 2005, 96, 375-398. [CrossRef]

40. Féret, J.-B.; Asner, G.P. Tree Species Discrimination in Tropical Forests Using Airborne Imaging Spectroscopy. IEEE Trans. Geosci. Remote Sens. 2013, 51, 73-84. [CrossRef]

41. Draper, F.C.; Baraloto, C.; Brodrick, P.G.; Phillips, O.L.; Martinez, R.V.; Honorio Coronado, E.N.; Baker, T.R.; Zárate Gómez, R.; Amasifuen Guerra, C.A.; Flores, M.; et al. Imaging Spectroscopy Predicts Variable Distance Decay across Contrasting Amazonian Tree Communities. J. Ecol. 2019, 107, 696-710. [CrossRef]

42. Vaglio Laurin, G.; Puletti, N.; Hawthorne, W.; Liesenberg, V.; Corona, P.; Papale, D.; Chen, Q.; Valentini, R. Discrimination of Tropical Forest Types, Dominant Species, and Mapping of Functional Guilds by Hyperspectral and Simulated Multispectral Sentinel-2 Data. Remote Sens. Environ. 2016, 176, 163-176. [CrossRef] 
43. Schneider, F.D.; Morsdorf, F.; Schmid, B.; Petchey, O.L.; Hueni, A.; Schimel, D.S.; Schaepman, M.E. Mapping Functional Diversity from Remotely Sensed Morphological and Physiological Forest Traits. Nat. Commun. 2017, 8, 1441. [CrossRef] [PubMed]

44. Asner, G.P.; Martin, R.E.; Knapp, D.E.; Tupayachi, R.; Anderson, C.B.; Sinca, F.; Vaughn, N.R.; Llactayo, W. Airborne Laser-Guided Imaging Spectroscopy to Map Forest Trait Diversity and Guide Conservation. Science 2017, 355, 385-389. [CrossRef] [PubMed]

45. Durán, S.M.; Martin, R.E.; Díaz, S.; Maitner, B.S.; Malhi, Y.; Salinas, N.; Shenkin, A.; Silman, M.R.; Wieczynski, D.J.; Asner, G.P.; et al. Informing Trait-Based Ecology by Assessing Remotely Sensed Functional Diversity across a Broad Tropical Temperature Gradient. Sci. Adv. 2019, 5, eaaw8114. [CrossRef]

46. Carreiras, J.M.B.; Jones, J.; Lucas, R.M.; Shimabukuro, Y.E. Mapping Major Land Cover Types and Retrieving the Age of Secondary Forests in the Brazilian Amazon by Combining Single-Date Optical and Radar Remote Sensing Data. Remote Sens. Environ. 2017, 194, 16-32. [CrossRef]

47. Fujiki, S.; Aoyagi, R.; Tanaka, A.; Imai, N.; Kusma, A.D.; Kurniawan, Y.; Lee, Y.F.; Sugau, J.B.; Pereira, J.T.; Samejima, H.; et al. Large-Scale Mapping of Tree-Community Composition as a Surrogate of Forest Degradation in Bornean Tropical Rain Forests. Land 2016, 5, 45. [CrossRef]

48. Palmer, M.W.; Earls, P.G.; Hoagland, B.W.; White, P.S.; Wohlgemuth, T. Quantitative Tools for Perfecting Species Lists. Environmetrics 2002, 13, 121-137. [CrossRef]

49. Schweiger, A.K.; Cavender-Bares, J.; Townsend, P.A.; Hobbie, S.E.; Madritch, M.D.; Wang, R.; Tilman, D.; Gamon, J.A. Plant Spectral Diversity Integrates Functional and Phylogenetic Components of Biodiversity and Predicts Ecosystem Function. Nat. Ecol. Evol. 2018, 2, 976-982. [CrossRef] [PubMed]

50. Cavender-Bares, J.; Gamon, J.A.; Hobbie, S.E.; Madritch, M.D.; Meireles, J.E.; Schweiger, A.K.; Townsend, P.A. Harnessing Plant Spectra to Integrate the Biodiversity Sciences across Biological and Spatial Scales. Am. J. Bot. 2017, 104, 966-969. [CrossRef] [PubMed]

51. Laliberté, E.; Schweiger, A.K.; Legendre, P. Partitioning Plant Spectral Diversity into Alpha and Beta Components. Ecol. Lett. 2020, 23, 370-380. [CrossRef] [PubMed]

52. Féret, J.-B.; Asner, G.P. Mapping Tropical Forest Canopy Diversity Using High-fidelity Imaging Spectroscopy. Ecol. Appl. Publ. Ecol. Soc. Am. 2014, 24, 1289-1296. [CrossRef] [PubMed]

53. Rocchini, D.; Balkenhol, N.; Carter, G.A.; Foody, G.M.; Gillespie, T.W.; He, K.S.; Kark, S.; Levin, N.; Lucas, K.; Luoto, M.; et al. Remotely Sensed Spectral Heterogeneity as a Proxy of Species Diversity: Recent Advances and Open Challenges. Ecol. Inform. 2010, 5, 318-329. [CrossRef]

54. Schäfer, E.; Heiskanen, J.; Heikinheimo, V.; Pellikka, P. Mapping Tree Species Diversity of a Tropical Montane Forest by Unsupervised Clustering of Airborne Imaging Spectroscopy Data. Ecol. Indic. 2016, 64, 49-58. [CrossRef]

55. Rocchini, D.; Luque, S.; Pettorelli, N.; Bastin, L.; Doktor, D.; Faedi, N.; Feilhauer, H.; Féret, J.-B.; Foody, G.M.; Gavish, Y.; et al. Measuring $\beta$-Diversity by Remote Sensing: A Challenge for Biodiversity Monitoring. Methods Ecol. Evol. 2018, 9, 1787-1798. [CrossRef]

56. Torresani, M.; Rocchini, D.; Sonnenschein, R.; Zebisch, M.; Hauffe, H.C.; Heym, M.; Pretzsch, H.; Tonon, G. Height Variation Hypothesis: A New Approach for Estimating Forest Species Diversity with CHM LiDAR Data. Ecol. Indic. 2020, 117, 106520. [CrossRef]

57. Chazdon, R.L. Second Growth: The Promise of Tropical Forest Regeneration in an Age of Deforestation; University of Chicago Press: Chicago, IL, USA, 2014; ISBN 978-0-226-11807-9.

58. Egler, F.E. Vegetation Science Concepts I. Initial Floristic Composition, a Factor in Old-Field Vegetation Development with 2 Figs. Veg. Acta Geobot. 1954, 4, 412-417. [CrossRef]

59. Finegan, B. Pattern and Process in Neotropical Secondary Rain Forests: The First 100 Years of Succession. Trends Ecol. Evol. 1996, 11, 119-124. [CrossRef]

60. Guariguata, M.R.; Ostertag, R. Neotropical Secondary Forest Succession: Changes in Structural and Functional Characteristics. For. Ecol. Manag. 2001, 148, 185-206. [CrossRef]

61. Bekele, F. The History of Cocoa Production in Trinidad and Tobago. In Proceedings of the APASTT Seminar, Re-Vitalisation of the Trinidad \& Tobago Cocoa Industry, St. Augustine, FL, USA, 20 September 2003; pp. 4-12.

62. NATT. Honouring Our Industrial Roots: Sugar, Cocoa, Asphalt and Oil; National Archives of Trinidad and Tobago: Port of Spain, Trinidad, 2018.

63. Kenefick, M.; Restall, R.L.; Hayes, F.E. Birds of Trinidad E Tobago; Bloomsbury Publishing PLC: London, UK, 2011; ISBN 978-14729-4152-7.

64. Arnold, H.; Deacon, A.E.; Hulme, M.F.; Sansom, A.; Jaggernauth, D.; Magurran, A.E. Contrasting Trends in Biodiversity of Birds and Trees during Succession Following Cacao Agroforest Abandonment. J. Appl. Ecol. 2021. [CrossRef]

65. QGIS Geographic Information System. Open Source Geospatial Foundation. Available online: http:/ / qgis.org (accessed on 1 March 2021).

66. ESA SP. Sentinel-2: ESA's Optical High-Resolution Mission for GMES Operational Services; Fletcher, K., European Space Agency, Eds.; ESA Communications: Noordwijk, The Netherlands, 2012; ISBN 978-92-9221-419-7.

67. Poilvé, H. Geoland2-BioPar Methods Compendium of MERIS FR Biophysical Products. 2010. Available online: https://www. researchgate.net/publication/265728093_geoland2_-_BioPar_Methods_Compendium_of_MERIS_FR_Biophysical_Products (accessed on 27 May 2021). [CrossRef] 
68. Hill, M.O. Diversity and Evenness: A Unifying Notation and Its Consequences. Ecology 1973, 54, 427-432. [CrossRef]

69. MacArthur, R.H. Patterns of Species Diversity. Biol. Rev. 1965, 40, 510-533. [CrossRef]

70. Chao, A.; Gotelli, N.J.; Hsieh, T.C.; Sander, E.L.; Ma, K.H.; Colwell, R.K.; Ellison, A.M. Rarefaction and Extrapolation with Hill Numbers: A Framework for Sampling and Estimation in Species Diversity Studies. Ecol. Monogr. 2014, 84, 45-67. [CrossRef]

71. R Core Team R: A Language and Environment for Statistical Computing; R Foundation for Statistical Computing: Vienna, Austria, 2017.

72. Bray, J.R.; Curtis, J.T. An Ordination of the Upland Forest Communities of Southern Wisconsin. Ecol. Monogr. 1957, 27, 325-349. [CrossRef]

73. McCarthy, B.C.; Magurran, A.E. Measuring Biological Diversity. J. Torrey Bot. Soc. 2004, 131, 277. [CrossRef]

74. Cavender-Bares, J.; Gamon, J.A.; Townsend, P.A. Remote Sensing of Plant Biodiversity; Springer: Berlin/Heidelberg, Germany, 2020; ISBN 978-3-030-33157-3.

75. Feret, J.; Boissieu, F. BiodivMapR: An r Package for A- and B-diversity Mapping Using Remotely Sensed Images. Methods Ecol. Evol. 2020, 11, 64-70. [CrossRef]

76. Ustin, S.L.; Gamon, J.A. Remote Sensing of Plant Functional Types: Tansley Review. New Phytol. 2010, 186, 795-816. [CrossRef] [PubMed]

77. Clerc, S.; Team, M. Sentinel-2 Data Quality Report (S2-PDGS-MPC-DQR). ESA Technical Report. 2016. Available online: https:// sentinel.esa.int/documents /247904/685211/Sentinel-2+Data+Quality+Report+(DQR)/f42497d3-611f-4165-bcc1-2f81421c646a (accessed on 27 May 2021).

78. Rohlf, F.J. An Empirical Comparison of Three Ordination Techniques in Numerical Taxonomy. Syst. Biol. 1972, 21, 271-280. [CrossRef]

79. Schober, P.; Boer, C.; Schwarte, L.A. Correlation Coefficients: Appropriate Use and Interpretation. Anesth. Analg. 2018, 126, 1763-1768. [CrossRef] [PubMed]

80. Koenker, R.; Leorato, S.; Peracchi, F. Distributional vs. Quantile Regression. SSRN Electron. J. 2013, 300, 1-45. [CrossRef]

81. Cade, B.S.; Noon, B.R. A Gentle Introduction to Quantile Regression for Ecologists. Front. Ecol. Environ. 2003, 1, 412-420. [CrossRef]

82. John, O. Robustness of Quantile Regression to Outliers. Am. J. Appl. Math. Stat. 2015, 3, 86-88. [CrossRef]

83. Galili, T. Dendextend: An R Package for Visualizing, Adjusting and Comparing Trees of Hierarchical Clustering. Bioinformatics 2015, 31, 3718-3720. [CrossRef]

84. Maechler, M.; Rousseeuw, P.; Struyf, A.; Hubert, M.; Hornik, K. Cluster: Cluster Analysis Basics and Extensions. Available online: https:/ /CRAN.R-project.org/package=cluster (accessed on 1 March 2021).

85. Helmer, E.H.; Ruzycki, T.S.; Benner, J.; Voggesser, S.M.; Scobie, B.P.; Park, C.; Fanning, D.W.; Ramnarine, S. Detailed Maps of Tropical Forest Types Are within Reach: Forest Tree Communities for Trinidad and Tobago Mapped with Multiseason Landsat and Multiseason Fine-Resolution Imagery. For. Ecol. Manag. 2012, 279, 147-166. [CrossRef]

86. Lebrija-Trejos, E.; Meave, J.A.; Poorter, L.; Pérez-García, E.A.; Bongers, F. Pathways, Mechanisms and Predictability of Vegetation Change during Tropical Dry Forest Succession. Perspect. Plant Ecol. Evol. Syst. 2010, 12, 267-275. [CrossRef]

87. Schoonmaker, P.; McKee, A. Species Composition and Diversity During Secondary Succession of Coniferous Forests in the Western Cascade Mountains of Oregon. For. Sci. 1988, 34, 960-979. [CrossRef]

88. Toky, O.P.; Ramakrishnan, P.S. Secondary Succession Following Slash and Burn Agriculture in North-Eastern India: I. Biomass, Litterfall and Productivity. J. Ecol. 1983, 71, 735-745. [CrossRef]

89. Wang, R.; Gamon, J.A.; Cavender-Bares, J.; Townsend, P.A.; Zygielbaum, A.I. The Spatial Sensitivity of the Spectral DiversityBiodiversity Relationship: An Experimental Test in a Prairie Grassland. Ecol. Appl. 2018, 28, 541-556. [CrossRef]

90. Aguirre-Gutiérrez, J.; Rifai, S.; Shenkin, A.; Oliveras, I.; Bentley, L.P.; Svátek, M.; Girardin, C.A.J.; Both, S.; Riutta, T.; Berenguer, E.; et al. Pantropical Modelling of Canopy Functional Traits Using Sentinel-2 Remote Sensing Data. Remote Sens. Environ. 2021, 252, 112122. [CrossRef]

91. Ma, X.; Mahecha, M.D.; Migliavacca, M.; van der Plas, F.; Benavides, R.; Ratcliffe, S.; Kattge, J.; Richter, R.; Musavi, T.; Baeten, L.; et al. Inferring Plant Functional Diversity from Space: The Potential of Sentinel-2. Remote Sens. Environ. 2019, $233,111368$. [CrossRef]

92. Sandor, M.E.; Chazdon, R.L. Remnant Trees Affect Species Composition but Not Structure of Tropical Second-Growth Forest. PLoS ONE 2014, 9, e83284. [CrossRef] [PubMed]

93. Wallis, C.I.B.; Brehm, G.; Donoso, D.A.; Fiedler, K.; Homeier, J.; Paulsch, D.; Süßenbach, D.; Tiede, Y.; Brandl, R.; Farwig, N.; et al. Remote Sensing Improves Prediction of Tropical Montane Species Diversity but Performance Differs among Taxa. Ecol. Indic. 2017, 83, 538-549. [CrossRef]

94. García-Montiel, D.C.; Scatena, F.N. The Effect of Human Activity on the Structure and Composition of a Tropical Forest in Puerto Rico. For. Ecol. Manag. 1994, 63, 57-78. [CrossRef]

95. Riswan, S.; Kenworthy, J.B.; Kartawinata, K. The Estimation of Temporal Processes in Tropical Rain Forest: A Study of Primary Mixed Dipterocarp Forest in Indonesia. J. Trop. Ecol. 1985, 1, 171-182. [CrossRef]

96. Guariguata, M.R.; Chazdon, R.L.; Denslow, J.S.; Dupuy, J.M.; Anderson, L. Structure and Floristics of Secondary and Old-Growth Forest Stands in Lowland Costa Rica. Plant Ecol. 1997, 132, 107-120. [CrossRef] 
97. Norden, N.; Chazdon, R.L.; Chao, A.; Jiang, Y.-H.; Vílchez-Alvarado, B. Resilience of Tropical Rain Forests: Tree Community Reassembly in Secondary Forests. Ecol. Lett. 2009, 12, 385-394. [CrossRef]

98. Ganivet, E.; Bloomberg, M. Towards Rapid Assessments of Tree Species Diversity and Structure in Fragmented Tropical Forests: A Review of Perspectives Offered by Remotely-Sensed and Field-Based Data. For. Ecol. Manag. 2019, 432, 40-53. [CrossRef]

99. Araújo-Santos, I.; Morante-Filho, J.C.; Oliveira, S.; Cabral, J.P.; Rocha-Santos, L.; Cassano, C.R.; Faria, D.; Benchimol, M. Seed Rain in Cocoa Agroforests Is Induced by Effects of Forest Loss on Frugivorous Birds and Management Intensity. Agric. Ecosyst. Environ. 2021, 313, 107380. [CrossRef]

100. Cabral, J.P.; Faria, D.; Morante-Filho, J.C. Landscape Composition Is More Important than Local Vegetation Structure for Understory Birds in Cocoa Agroforestry Systems. For. Ecol. Manag. 2021, 481, 118704. [CrossRef]

101. Cubiña, A.; Aide, T.M. The Effect of Distance from Forest Edge on Seed Rain and Soil Seed Bank in a Tropical Pasture. Biotropica 2001, 33, 260-267. [CrossRef]

102. Hooper, E.R.; Legendre, P.; Condit, R. Factors Affecting Community Composition of Forest Regeneration in Deforested, Abandoned Land in Panama. Ecology 2004, 85, 3313-3326. [CrossRef]

103. Hyatt, L.A.; Casper, B.B. Seed Bank Formation during Early Secondary Succession in a Temperate Deciduous Forest. J. Ecol. 2000, 88, 516-527. [CrossRef]

104. Rolim, S.G.; Machado, R.E.; Pillar, V.D. Divergence in a Neotropical Forest during 33 Years of Succession Following Clear-Cutting. J. Veg. Sci. 2017, 28, 495-503. [CrossRef]

105. Franklin, J.F.; Spies, T.A.; Pelt, R.V.; Carey, A.B.; Thornburgh, D.A.; Berg, D.R.; Lindenmayer, D.B.; Harmon, M.E.; Keeton, W.S.; Shaw, D.C.; et al. Disturbances and Structural Development of Natural Forest Ecosystems with Silvicultural Implications, Using Douglas-Fir Forests as an Example. For. Ecol. Manag. 2002, 155, 399-423. [CrossRef] 